\title{
PREDICTING THE FLEXURAL RESPONSE OF A REINFORCED CONCRETE BEAM USING THE FRACTURE-PLASTIC MODEL
}

\author{
Asdam Tambusay ${ }^{a^{*}}$ and Priyo Suprobo ${ }^{\mathrm{a}}$
}

\begin{abstract}
This paper describes an attempt to predict the flexural response of a reinforced concrete (RC) beam using nonlinear finite element analysis. To facilitate direct comparison, the beam was tested experimentally under four-point bending with the load increased monotonically. The load-deflection response, crack pattern and failure mode were observed in the experiment. Analysis incorporating the application of ATENA 3D was performed using the fracture-plastic model which is based on the classical orthotropic smeared crack formulation and crack band model. The applicability of this model was demonstrated through detailed simulation of $R C$ beam with identical geometry, reinforcement arrangement, and material properties. From this study, it is found that the overall predicted responses are in very good agreement to those obtained from the experiment. It is also found that the feature in ATENA enables the presentation of reasonably maximum principal strains of concrete and rebar elements which can, therefore, be associated with the predicted crack bands.
\end{abstract}

Keywords: ATENA, fracture-plastic model, reinforced concrete beam, flexure, smeared crack, fixed crack.

\section{INTRODUCTION}

It is well known that the flexural behavior of $\mathrm{RC}$ beam greatly depends on the reinforcing ratio either in the form of longitudinal rebars and/or fiber-reinforced polymers (FRP) [1-10]. These reinforcements should be placed at locations where high tensile stresses occur to ensure that the beam will not undergo premature failure as a result of the brittle nature of concrete. The use of reinforcements is also essential in this regard as they can provide adequate cracking control which is also important for providing the required strength and ductility [11].

In the design of a simply supported RC beam element, it is imperative to place the longitudinal bars at the bottom of the beam section. When gravity loads are applied at the top, the beam will deform downward, and the bottom bars will provide resistance once the tensile strength of concrete is released. Nevertheless, the latter works merely should the applied positive moments occur throughout the beam span, suggesting the top beam section merely undergoes compression. In complex cases such as in buildings, however, the longitudinal bars shall be provided at the bottom and the top section. This is due to the presence of applied positive and negative moments that arise simultaneously due to, for instance, fixed or rigid joint connections being the case. Of importance is also to withstand envelope forces due to seismic loads. Consequently, the increase in ductility may be constrained and mainly depends on both ratios of top and bottom steel bars provided. Furthermore, when the ductile plateau is ceased during highly nonlinear behavior, failure may be associated with compression crushing near the loading source.

In accordance with design specifications for general concrete structure buildings, such as ACI 318-14 [12], NZS 3101:2006 [13], CSA A23.3-04 [14], and SNI 28472019 [15], the minimum and maximum requirements for reinforcing bar ratios are overtly specified and can simply be calculated based upon the yield strength of reinforcing bars and compressive strength of concrete. The provision of minimum ratio shall be deemed to provide cracking

${ }^{a}$ Lecturer in the Civil Engineering Department, Institut Teknologi Sepuluh Nopember, ITS Campus, Sukolilo, Surabaya 60111, Indonesia. Corresponding author email address: asdam@its.ac.id resistance due to creep and shrinkage. The requirement for the maximum ratio is equally specified to prevent compression failure of concrete before the yielding mechanism of reinforcing bars. This type of design is over-reinforced and exhibits less sign of warning when the failure is imminent.

Referring to what has been addressed above, this current limited work is aimed to address and to compare the nonlinear flexural behavior of a doubly reinforced concrete beam. The response of the beam is discussed from two different work aspects: laboratory experiment and computer simulation utilizing the application of a sophisticated finite element software package developed by Červenka Consulting Ltd. [16]. Of interest are the results with regard to load capacity, deflection at beam midspan, crack pattern, mode of failure, and principal strains in conjunction with crack bands.

In ATENA, constitutive laws of concrete can be modeled using either the SBETA or the fracture-plastic model [17-20]. In the latter model, behavior of concrete is treated based on the combination of tension (fracturing) and compression (plastic) [21].

The material axes of cracked concrete and the axes of orthotropy can be defined by two models: fixed or rotating crack. In the former model, crack orientation is regarded as being geometrically fixed once generated, and anisotropy is intrinsically deemed since normal and shear stress transfers are independently modeled. Therefore, it allows the crack model geometrically close to reality. In the latter model, on the other hand, the crack direction is treated to always coincides with the principal stress direction of average strain and reorient with a change in the crack opening orientation. Furthermore, the computation is also simplified as shear slip and shear stress transfer due to aggregate interlock are excluded. In this study, the smeared fixed crack model is employed.

\section{RESEARCH SIGNIFICANCE}

When performing the design on a reinforced concrete beam, practicing engineers typically must deal with longitudinal forces equilibrium on critical sections and ensure the compatibility of longitudinal strains across the depth of the beam. Although the process is relatively straightforward due to its simplicity, the engineers tend to presume that the design is generally singly reinforced and 
overlook the influence of compression bars. To bridge this misconception, improved insights into the flexural failure mechanism is addressed by employing the use of a fracture-plastic model which is embedded in the smeared fixed crack approach.

\section{METHODOLOGY}

The research methodology in this paper comprises two different work which will be detailed under separated sub-sections. The experimental program describes the fabrication and testing of a beam specimen while the numerical model describes the constitutive model for concrete and steel bars, in addition to modeling strategy implemented for simulation.

\section{A. Experimental program}

A small-scale of doubly reinforced concrete beam designed with normal strength concrete and hot-formed steel bars was fabricated in the workshop of PT. Wijaya Karya Beton in Pasuruan. The beam had five longitudinal bars: three served as tension (bottom) bars and the other two as compression (top) bars. Two-legged rectangular closed stirrups were provided along the span, past the support, at a constant spacing of $100 \mathrm{~mm}$ to prevent the development of localized diagonal splitting cracks across the shear span. Figure 1 displays the schematic of beam geometry, with details of cross-section and steel bar listed in Table 1 and Table 2, respectively.

The concrete mix design used to fabricate the beam is listed in Table 3 . The concrete was produced in a single batch using a 150-liter pan mixer with a water-to-cement ratio of 0.3 . The maximum grain size of coarse and fine aggregates used for the beam was $10 \mathrm{~mm}$ and $<3 \mathrm{~mm}$, respectively. CEM I 42.5 R-NA Portland cement referred to as [22] was used. To increase the workability, a small dosage of superplasticizer TamCem 60 RA was also used.

The concrete was poured into the steel formwork with dimensions of $0.1 \times 0.2 \times 2.0 \mathrm{~m}^{3}$ followed by the casting of three standard $0.3 \mathrm{~m}$ height cylinders to obtain the mean compressive strength $f_{c}^{\prime}$ as specified according to ASTM C39/C39M-14 [23]. The result of the 28-day mean compressive stress of concrete is summarized in Table 3.

After 28 days of moist curing, the beam was transferred to the test zone. Before testing, the surface of the beam was sprayed white and $50 \mathrm{~mm}$ square gridlines were prepared at the half span while the other half was manually marked with black random speckle pattern for
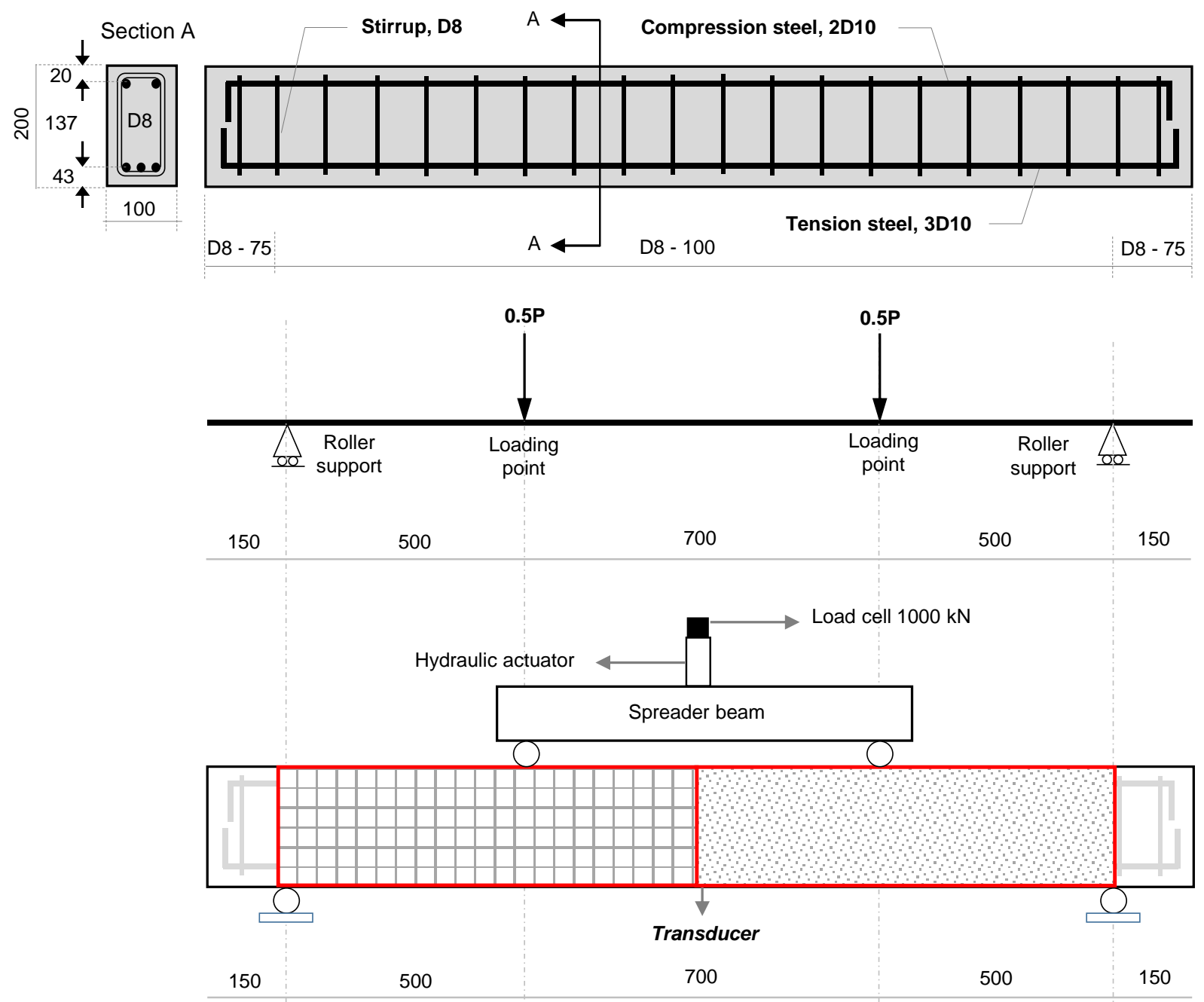

Length unit is in 'millimeter'

Figure 1. Schematic drawing of beam dimensions and loading setup. 
Table 1. Details of the beam cross-section.

\begin{tabular}{cccccc}
\hline $\begin{array}{c}\text { Width } b \\
(\mathrm{~mm})\end{array}$ & $\begin{array}{c}\text { Height } h \\
(\mathrm{~mm})\end{array}$ & $\begin{array}{c}\text { Effective depth } d \\
(\mathrm{~mm})\end{array}$ & $\begin{array}{c}\text { Length } L \\
(\mathrm{~mm})\end{array}$ & $\begin{array}{c}\text { Span } a \\
(\mathrm{~mm})\end{array}$ & $a / d$ \\
\hline 100 & 200 & 157 & 2000 & 500 & 3.2 \\
\hline
\end{tabular}

Table 2. Tensile properties of reinforcing bars

\begin{tabular}{ccccccc}
\hline $\begin{array}{c}\text { Diameter } \\
(\mathrm{mm})\end{array}$ & $\begin{array}{c}\text { Area } \\
\left(\mathrm{mm}^{2}\right)\end{array}$ & $\begin{array}{c}\text { Yield } \\
\text { strength } f_{y} \\
(\mathrm{MPa})\end{array}$ & $\begin{array}{c}\text { Ultimate } \\
\text { strength } f_{u} \\
(\mathrm{MPa})\end{array}$ & $\begin{array}{c}\text { Elastic } \\
\text { modulus } E_{s} \\
(\mathrm{GPa})\end{array}$ & $\begin{array}{c}\text { Strain } \\
\text { hardening } \varepsilon_{s h} \\
(\%)\end{array}$ & $\begin{array}{c}\text { Ultimate } \\
\text { strain } \varepsilon_{u} \\
(\%)\end{array}$ \\
\hline 8 & 50.3 & 397 & 540 & 200 & 1.1 & 15.8 \\
10 & 78.5 & 559 & 649 & 200 & 1.4 & 10.3 \\
\hline
\end{tabular}

Table 3. Summary of concrete mix and 28-day compressive strength.

\begin{tabular}{ccccc}
\hline $\begin{array}{c}\text { CEM I } \\
\left(\mathrm{kg} / \mathrm{m}^{3}\right)\end{array}$ & $\begin{array}{c}10 \mathrm{~mm} \\
\left(\mathrm{~kg} / \mathrm{m}^{3}\right)\end{array}$ & $\begin{array}{c}\text { Fine }(<3 \mathrm{~mm}) \\
\left(\mathrm{kg} / \mathrm{m}^{3}\right)\end{array}$ & $\begin{array}{c}\text { HRWR } \\
\left(\mathrm{g} / \mathrm{m}^{3}\right)\end{array}$ & $\begin{array}{c}f^{\prime}{ }_{c} \\
(\mathrm{MPa})\end{array}$ \\
\hline 525 & 1054 & 764 & 5.5 & 47.2 \\
\hline
\end{tabular}

digital image correlation (DIC) technique [24-26]. Upon the preparation which took one day, the beam was finally tested using a rigid reaction frame. The schematic of loading setup is illustrated in Figure 1. During testing, the load was recorded using $1 \mathrm{MN}$ Tokyo Sokki load cell which was placed onto the rigid steel spreader beam. The midspan displacement was monitored using a $100 \mathrm{~mm}$ transducer positioned underneath the beam. The load and deflection throughout testing were recorded using Tokyo Sokki Data Logger TDS-630. Throughout testing, the formation of cracks across the span was also manually observed using color permanent markers.

\section{B. Finite element model}

The nonlinear concrete material in this study was modeled by a fracture-plastic constitutive model (referred to as 3DNonlinearCementitious2) [17]. Employing this model, the tensile behavior of concrete is treated by fracture mechanics whereas for compression by plasticity [17].

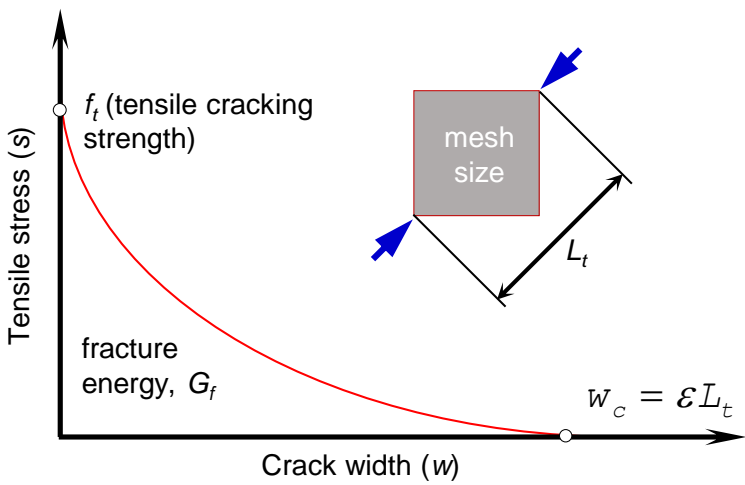

Figure 2. Tensile model for concrete [27].

The tension (fracturing) model is developed based upon the classical orthotropic smeared crack formulation and crack band model. Rankine failure criterion with the exponential softening branch is used for concrete cracking which is derived from strains and stresses which the orientation is determined by the principal directions at the onset of cracking [17]. As shown in Figure 2, the tensile stress-strain law of concrete consists of two parts (i.e. tension before and after cracking). Before cracking, the behavior is assumed linear elastic. Beyond this, the concrete undergoes exponential softening which is developed following crack-opening law $w_{c}$ and fracture energy [27]. This formulation is suitable for modeling the crack propagation in concrete.

The compression (plastic) model of concrete is developed based on Menétrey-Willam failure surface [21]. In this model, the stress-strain relation of concrete consists of two formulations (i.e. hardening and softening). In the hardening part, the formulation is based on strain and it follows the recommendation from CEBFIP [28]. In the descending (softening) part, the formulation is based on plastic displacement [29]. The softening law in compression employs the concept where the post-peak compressive displacement and energy dissipation are localized in a plane normal to the direction of compressive principal stress.

The following describes the parameters used in the simulation. Of importance in 3DNonlinearCementitious2 are parameters required for the definition of concrete. These parameters are available in five library boxes and they should be taken with care as they affect the results.

In the basic library, parameters for consideration were cylinder compressive strength $f_{c}^{\prime}$ and tensile strength $f_{t}$ derived from the cubic compressive stress $f_{c u}$, Poisson's ratio $v$ and elastic modulus $E_{c}$. These parameters can be calculated based on the equations provided in the following manner [28]:

$$
\begin{gathered}
f_{c}^{\prime}=-0.85 f_{c u} \\
f_{t}=0.24 f_{c u}^{\frac{2}{3}} \\
E_{c}=\left(6000-15.5 f_{c u}\right) \sqrt{f_{c u}}
\end{gathered}
$$

In the tensile library, the parameter was fracture energy $G_{f}$ which is calculated in the following manner:

$$
G_{f}=G_{f}\left(\frac{f_{c}^{\prime}}{10}\right)^{0.7}
$$


where $G_{f 0}=0.030 \mathrm{~N} / \mathrm{mm}$ is the base value of fracture energy obtained from the size of $16 \mathrm{~mm}$ aggregate. Other considerations were crack spacing and tension stiffening. However, they were not considered in this study.

$$
\varepsilon_{c p}=\frac{f_{c}^{\prime}}{E_{c}}
$$

In the compression library, parameters considered were critical compressive displacement $w_{d}$ of $-0.5 \mathrm{~mm}$, plastic strain at compressive strength $\varepsilon_{c p}$ calculated using Eqn. (5) and reduction of compressive strength due to cracks $\left(r_{c, \text { lim }}=0.8\right)$.

In the shear library, parameters considered were the crack shear stiffening factor of 20 (used as default) and aggregate interlock MCF. The latter was activated to account for the increase of nominal shear strength provided by concrete. In the miscellaneous library, all parameters used for simulation were left as is, including the crack model coefficient of 1.0 for fixed crack model.

It is noteworthy that the fracture-plastic constitutive model incorporating in 3DNonlinearCementitious2 of ATENA software is considered as an easy-to-adopt model as it only requires the information of cubic compressive strength of concrete $f_{c u}$, whilst other input parameters can be devised using a set of relations from $f_{c u}$ as presented in series of formulations discussed earlier.

The steel bars were modeled using one-dimensional discrete element embedded in the concrete. The specific stress-strain relations used in this study was bilinear with strain hardening. The bond between reinforcing steel and concrete was assumed in perfect connection (no bond-slip consideration).

In this study, the beam was modeled using an 8-node hexahedral (brick) linear elements. A typical mesh size of $20 \mathrm{~mm}$ was used and consistently applied throughout beam dimensions. The loading and support steel plates were modeled using 3D elastic isotropic material as they were assumed rigid. The mesh type used for the latter was the linear tetrahedral element which is the default mesh generated by the software. For clarity, the mesh and boundary conditions of half of the beam are displayed in Figure 3.

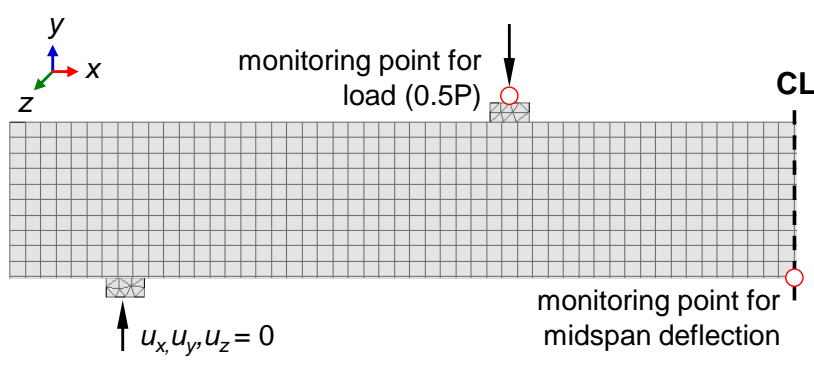

Figure 3. Finite element mesh and boundary conditions.

The analysis for the beam was simulated using prescribed displacement increasing gradually with a rate of $1.0 \mathrm{~mm}$ per step until failure. Two-point load applied at the top, the beam deflection at bottom midspan were all monitored at each displacement increment. The computed load and deflection were then compared with the response obtained from the experiment.

In this study, a standard Newton-Raphson iterative solution with a tangent stiffness and permissible error of residual forces of $1.0 \%$ was used as analysis solver. Another solver is also available in the library, such as arch length iterative solution. However, the latter was not selected as it is more appropriate for simulation of high strength concrete attributes which are critical for capturing the behavioral response of loading snapback as a result of high brittleness of concrete.

\section{ANALYSIS AND DISCUSSIONS}

A. Load-deflection response

A comparison of the observed and predicted loadcarrying capacity plotted against midspan deflection is presented in Figure 4 with documentation of crack pattern of half of the beam shown in Figure 5.

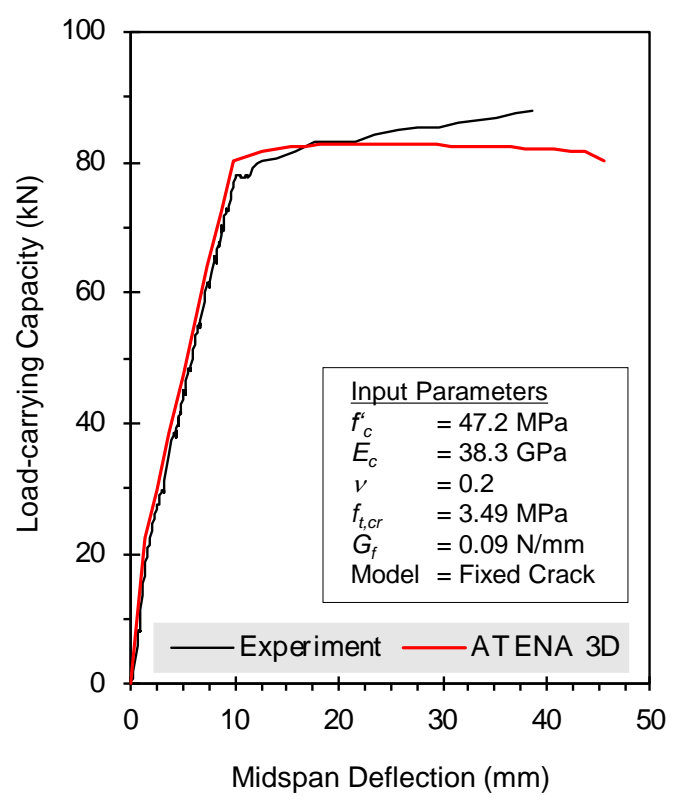

Figure 4. Load-deflection response.

With regard to load-deflection responses, it is found that the fracture-plastic model is capable of accurately capturing similar stiffness prior to the yielding of bottom reinforcing bars. The gradient of stiffness is reasonably identical, suggesting the observed and predicted loaddeflection has no difference whatsoever. It is also apparent from Figure 4 that the initial stiffness during the linear elastic response is relatively stiff due to significant increase of load capacity, whilst the increase of beam deflection is trivial. This continues until the load reaches $22 \mathrm{kN}$ where the vertical crack forms for the first time due to concrete fracturing (see Figure 5(a)). The stiffness upon this initial cracking is still proportional although it starts to deviate from linearity. Accordingly, in this stage of loading, the tensile strength is now mainly carried by steel bars as concrete is no longer resisting the tensile stress. As a result, the development of numbers of cracks is now visible across the midspan and propagates vastly toward the neutral axis (see Figure 5(b)).

At the loading stage of $80 \mathrm{kN}$ (see Figure 4), it is noticeable that the reinforcing bars at critical sections have started to undergo yielding mechanism which, from 
the figure presented, is associated with an insignificant increase of load compared to deflection. This indicates that beam stiffness is greatly reduced.

As shown in Figure 4, it is also apparent that notable nonlinear plateau from the experiment and analysis are easily identified. The observed specimen exhibits a marginal increase of load up to $88 \mathrm{kN}$ before the sudden drop of load due to compression crushing near the point load (see Figure 5(c)). Conversely, the predicted load upon the nonlinear regime shows a trivial gradual decrease with a somewhat longer ductile plateau than that of the observed specimen. Despite this slight discrepancy, which may be originating from several influencing factors such as sensitivity of load cell readings, plate dimensions or the stiffness of test rig, the predicted behavioral response is still reasonably accurate and hence can be the subject for further study.

As displayed in Figure 5(c) and 5(d), the photos of the crack pattern obtained at failure state noticeably demonstrate the similar pattern which is highlighted by three natures: vertical cracks, fan-shaped inclined cracks, and compression crushing. Of interest is the evidence being presented that ATENA is capable of accurately predicting the overall flexural responses of the beam. The key feature of crack bands as rendered in Figure 5 also provides additional evidence- whilst the pre-processing modeling technique is generally straightforward and easyto-perform, the applicability of the software is capable of exhibiting representation of crack-alike which is not readily available in many finite element software.
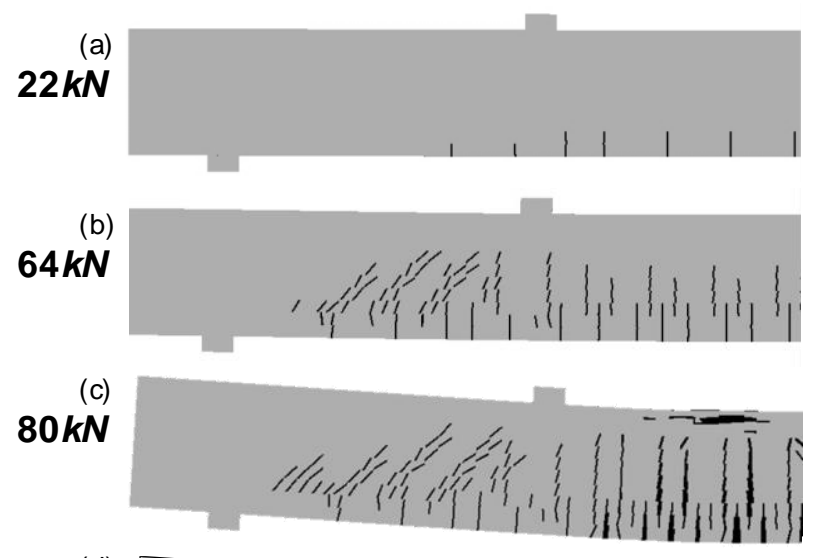

$88 k N$

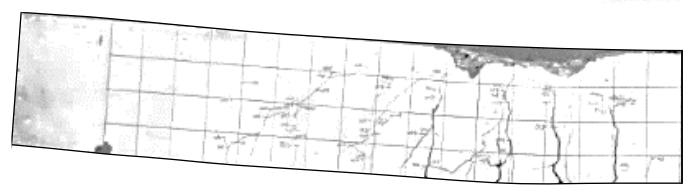

Figure 5. (a)-(c) Successive formation of predicted crack pattern resulted from ATENA, and (d) Final crack pattern of observed specimen.

\section{B. Maximum principal strain}

To gain in-depth insights into the flexural failure mechanisms of the beam, the maximum principal strain extracted from ATENA Studio is discussed herein. The maximum principal strains occurring within the critical region of the concrete elements are displayed in Figure 6. It is apparent from the figure that the presentation of maximum principal strain is recognizably similar to the observed crack pattern and crack bands, indicating a high degree of accuracy.

At the load of $22 \mathrm{kN}$, the onset of flexural strain bands takes place at the tension face of the beam. The concrete tensile strain measured in this stage is circa $0.0013 \mathrm{~m} / \mathrm{m}$ which is greater than the tensile cracking limit (i.e. $0.0001 \mathrm{~m} / \mathrm{m}$ ). As the loading is increased until $64 \mathrm{kN}$, the flexural strain bands adjacent to support start to shift, forming inclined strain bands with tips radiating towards the loading point. It is noteworthy that one must be aware of this strain formation as the propagation may lead to an unexpected localized shear crack with vast widening, should transverse bars are inadequately provided. It is also noticeable at this stage that new formation of concrete fracturing near the existing ones has occurred.

As the load is further increased at the level of $80 \mathrm{kN}$ when rebars are yielded, the widening of vertical existing strain bands is apparent, and the proportional increase of load-carrying capacity is now prevented. However, it is interesting to note that the existing forms of inclined strain bands have no longer extended as the localized widening occurs merely within the constant moment region. This is a good sign of design as shear failure is hampered due to the proper consideration of shear spanto-depth ratio as well as adequate stirrups.

As the load is roughly constant upon the yielding of steel bars and deflection is increased notably, the beam eventually fails due to concrete crushing. This failure, as stated, is linked to the effect of compression bars which tend to hinder beam deflection, prompting flexurecompression failure once the nominal compressive strain of concrete is exceeded.

Figure 7 highlights the maximum principal strain acting at longitudinal bars and stirrups. It is interesting to note that the stirrups and top bars are not considerably affected by the load since the strain development is negligible. On the contrary, the localized strains are smeared at bottom bars over the midspan and positioned precisely at the fracture strain of concrete elements. The red line, as identified in certain parts of bottom bars, indicates the principal strain magnitude of $0.035 \mathrm{~m} / \mathrm{m}$ which is beyond the limit of yield strain of $0.003 \mathrm{~m} / \mathrm{m}$ thereby signifying the rebars have significantly yielded.

\section{CONCLUSIONS}

This paper presents the systematic analysis of nonlinear finite element procedure in the context of fixed cracks approach using the fracture-plastic model which is based on classical orthotropic smeared crack formulation and crack band model. The experimental investigation was addressed to facilitate direct comparison with regard to the extent of accuracy of the software for predicting the flexural behavior of a simply supported beam. Based on the limited experimental and analytical work presented, it can be concluded that the use of ATENA software is capable of demonstrating similar behavioral responses as those obtained from the experimental investigation. These incorporate the load-deflection response, crack pattern, and failure more. A path-dependent smeared crack model attributed in ATENA is also capable of demonstrating 

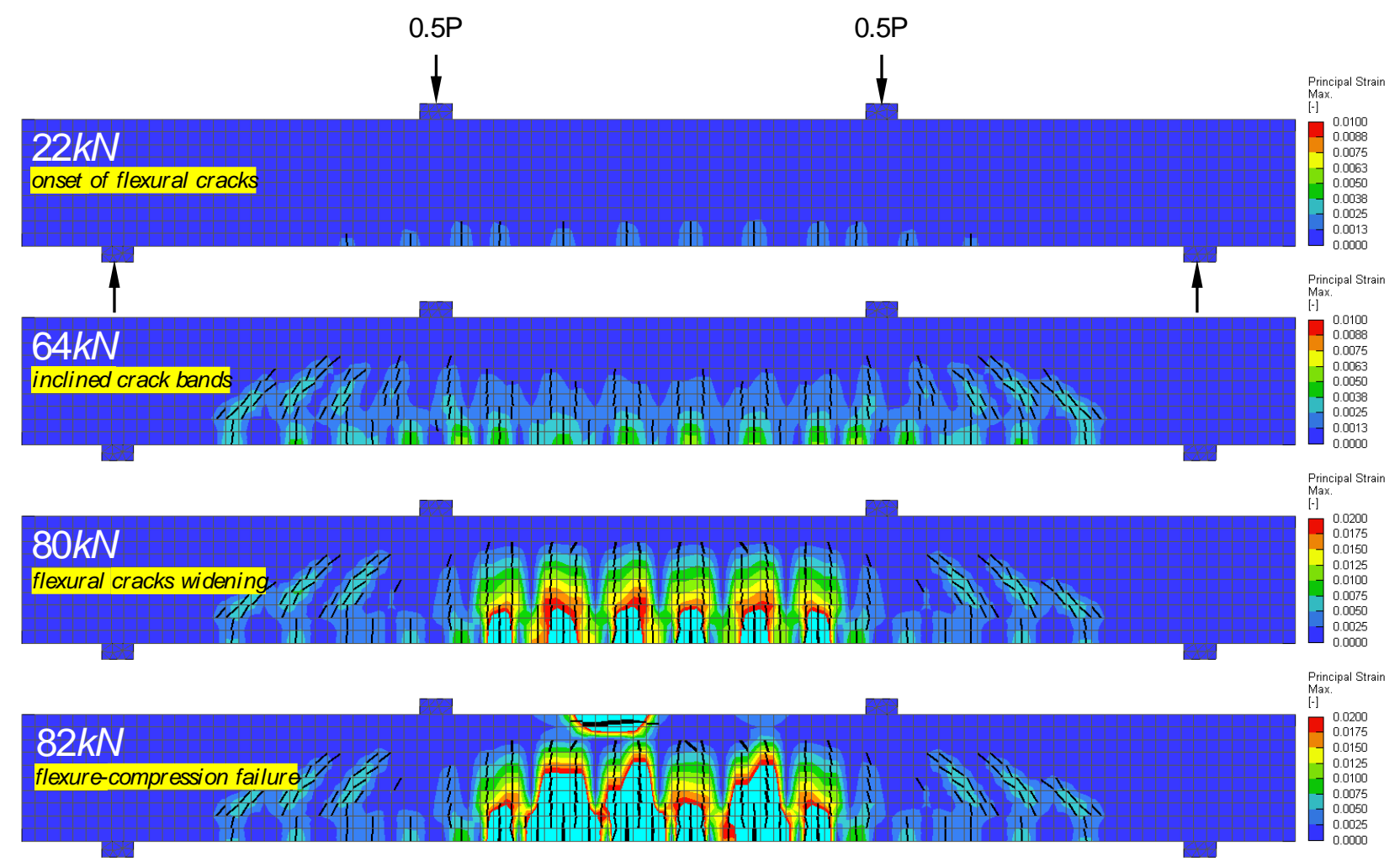

Figure 6. Maximum principal strain of concrete elements.

Maximum strain of 0.035 (steel has yielded))

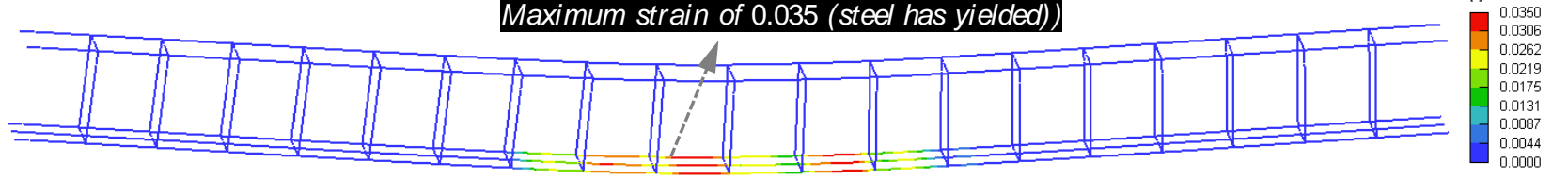

Figure 7. Maximum principal strain of rebar elements.

reasonably representation of damage processes which can be characterized by the maximum principal strain of concrete and reinforcing bar. The key feature of the crack band model provided in ATENA indeed represents the discrete cracks visualization which are indistinguishable to those shown in the observed reinforced concrete beam. More importantly, knowledge transfer from ATENA documentation is inclusive which has helped greatly in the course of modeling and results interpretation.

\section{ACKNOWLEDGMENT}

The authors wish to acknowledge the financial support from the Ministry of Research, Technology, and Higher Education of the Republic of Indonesia, the in-kind and technical support from PT. Wijaya Karya Beton Tbk. for prioritizing the experiment in their workshop in Pasuruan, and from the Laboratory of Concrete and Building Materials at Institute of Technology Sepuluh Nopember for providing the licensed ATENA software. Thanks also to I. Komara, M.A. Bastian, W.N Oktaviani, M. Mooy, and G.J.P Ghewa for their assistance in the experimental work.

\section{REFERENCES}

[1] S. A. Ashour, "Effect of compressive strength and tensile reinforcement ratio on flexural behavior of high-strength concrete beams," Engineering Structures, vol. 22, no. 5, pp. 413423, 2000.

[2] M. Thériault and B. Benmokrane, "Effects of FRP reinforcement ratio and concrete strength on flexural behavior of concrete beams," Journal of Composites for Construction, vol. 2, no. 1, pp. 716, 1998.

[3] W. N. Oktaviani, A. Tambusay, I. Komara, W. Sutrisno, F. Faimun, and P. Suprobo, "Flexural behavior of a reinforced concrete beam blended with fly ash as supplementary material," IOP Conference Series: Earth and Environmental Science, 2020.

[4] S. A. Ashour, "Effect of the concrete compressive strength and tensile reinforcement ratio on the flexural behavior of fibrous concrete beams," Engineering Structures, vol. 22, no. 9, pp. 1145-1158, 2000. 
[5] A. Meda, F. Minelli, G. A. Plizzari, "Flexural behavior of RC beams in fibre reinforced concrete," Composites Part B: Engineering, vol. 43, no. 8, pp. 2930-2937, 2012.

[6] M. A. Bastian, A. Tambusay, I. Komara, W. Sutrisno, D. Irawan, and P. Suprobo, "Enhancing the ductility of a reinforced concrete beam using engineered cementitious composite," IOP Conference Series: Earth and Environmental Science, 2020.

[7] A. N. Dancygier and Z. Savir, "Flexural behavior of HSFRC with low reinforcement ratios," Engineering Structures, vol. 28, no. 11, pp. 1503-1512, 2006.

[8] R. J. Gravina and S. T. Smith, "Flexural behavior of intermediate concrete beams reinforced with FRP bars," Engineering Structures, vol. 30, no. 9, pp. 2370-2380, 2008.

[9] S. H. Alsayed, "Flexural behavior of concrete beams reinforced with GFRP bars," Cement and Concrete Composites, vol. 20, no. 1, pp. 1-11, 1998.

[10] M. N. Habeeb and A. F. Ashour, "Flexural behavior of continuous GFRP reinforced concrete beams," Journal of Composites for Construction, vol. 12, no. 2, pp. 115-124, 2008.

[11] A. K. H. Kwan, J. C. M. Ho, and H. J. Pam, "Flexural strength and ductility of reinforced concrete beams," Proceedings of the Institution of Civil Engineers - Structures and Buildings, vol. 152, no. 4, pp. 361-369, 2002.

[12] ACI Committee, "Building code requirements for structural concrete (ACI 318M-14) and commentary (ACI 318RM-14)," American Concrete Institute, 2014.

[13] NZS Committee, "Concrete structures standardthe design of concrete structures incorporating amendment No. 1 \& 2 (NZS 3101 Part 1: 2006A1\&A2)," NZS Wellington New Zealand, 2006.

[14] CSA Committee, "Design of concrete structures," Canadian Standards Association, 2004.

[15] BSN Committee, "Persyaratan beton struktur untuk bangunan gedung dan penjelasan (SNI 2847:2019), Badan Standardisasi Nasional, 2019.

[16] Červenka Consulting, “ATENA for non-linear finite element analysis of reinforced concrete structures," https://www.cervenka.cz/company/, accessed in January 2020.

[17] V. Červenka, L. Jendele, and J. Červenka, "ATENA Program Cocumentation-part 1: Theory, Prague, December 3, 2018.
[18] V. Červenka, "Constitutive model for cracked reinforced concrete," ACI Structural Journal, vol. 82, no. 6, pp. 877-882, 1985.

[19] V. Červenka, J. Červenka, R. Pukl, and T. Sajdlova, "Prediction of shear failure of large beam based on fracture mechanics," $9^{\text {th }}$ International Conference on Fracture Mechanics of Concrete and Concrete Structures (FraMCoS9), 2016.

[20] L. Kadlec and V. Červenka, "Uncertainty of numerical models for punching resistance of RC slabs," FIB Symposium Copenhagen, Denmark, 2015.

[21] P. Menétrey and K. J. Willam, "Triaxial failure criterion for concrete and its generalization," ACI Structural Journal, vol. 95, no. 3, pp. 311318, 1995.

[22] DIN EN 197-1:2011-11, “Cement-part 1: composition, specifications and conformity criteria for common cements," German Standard, 2011.

[23] ASTM Committee, "Standard test method for compressive strength of cylindrical concrete specimens (C39-C39M-14)," American Standard for Testing Materials, 2014.

[24] A. Tambusay, B. Suryanto, and P. Suprobo, "Visualization of shear cracks in a reinforced concrete beam using the digital image correlation," International Journal on Advanced Science, Engineering and Information Technology, vol. 8, no. 2, pp. 573-578, 2018.

[25] B. Suryanto, A. Tambusay, and P. Suprobo, "Crack mapping on shear-critical reinforced concrete beams using an open-source digital image correlation software," Civil Engineering Dimension, vol. 19, no. 2, pp. 93-98, 2017.

[26] B. Suryanto, G. Staniforth, J. Kim, E. Gebreyouhannes, N. Chijiwa, F. Chikako, and P. $\mathrm{K}$. Woodward, "Investigating the mechanism of shear fatigue in reinforced concrete beams subjected to pulsating and moving loads using digital image correlation," MATEC Web Conferences, vol. 258, pp. 1-9, 2019.

[27] D. A. Hordijk, "Local approach to fatigue of concrete," Doctoral Dissertation, Delft University of Technology, 1991.

[28] CEB-FIP, "Comité Euro-International du Béton (CEB-FIP Model Code 1990), Information Bulleting No. 195, 1990.

[29] J. G. M. V. Mier, "Multiaxial strain-softening of concrete, part 1: fracture," Materials and Structures, vol. 19, no. 111, 1986. 